
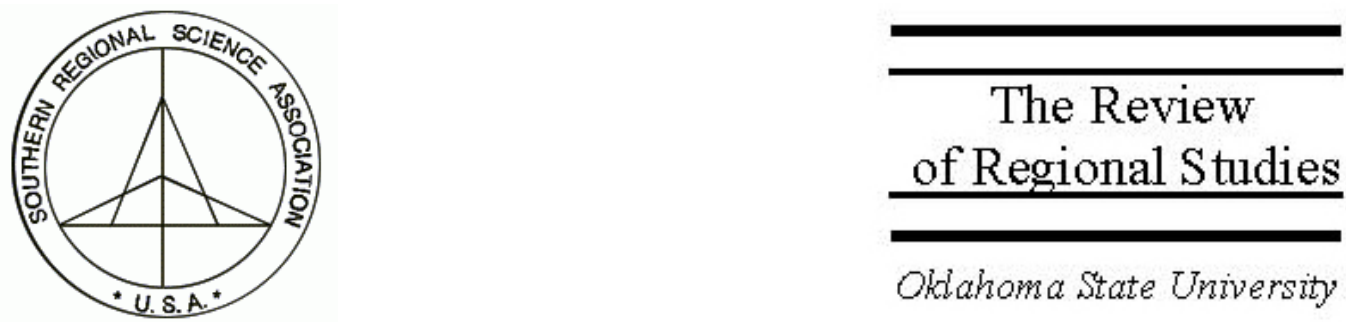

\title{
The Impacts of School Choice on Regional Economic Growth
}

\author{
Kerry A. King
}

Sam and Irene Black School of Business, Department of Economics, Penn State Erie, The Behrend College, 5091 Station Road, Erie, PA 16563, e-mail: kak38@psu.edu

\begin{abstract}
School choice has recently become a common approach to address the problems facing education in the United States. Previous literature focuses predominately on the effects of school choice on student achievement levels. In this paper, I use county-level data to study the effects of school choice on regional economic growth. In particular, I use charter schools, vouchers, and open enrollment to measure the effects of school choice on population growth. The results indicate that charter schools have a positive influence on the growth of regions while vouchers and open enrollment exhibit no significant impacts during the time period estimated.
\end{abstract}

Keywords: Education; Growth; Regional; School choice; Vouchers

JEL classification: I20; R00

I would like to thank Todd M. Nesbit and two anonymous referees for their helpful comments and suggestions. 


\section{INTRODUCTION}

Although the debate over school choice has just recently become a major topic in education reform, implementing choice and competition in education was first discussed by Adam Smith. The following is an excerpt from An Inquiry Into the Nature and Causes of the Wealth of Nations, 1776 (Book 5, Chapter 1, Article 2).

The expense of the institutions for education and religions instruction, is likewise, no doubt, beneficial to the whole society, and may, therefore, without injustice, be defrayed by the general contribution of the whole society. This expense, however, might perhaps with equal propriety, and even with some advantage, be defrayed altogether by those who receive the immediate benefit of such education and instruction, or by the voluntary contribution of those who think they have occasion for either the one or the other.

Smith also points out that the professors who receive money from a general fund rather than on a per-student basis will lack motivation and incentive. Giving students the opportunity to choose the professors under whom to study creates an environment where the professor must compete for students by creating a reputation for providing high quality instruction. This idea of empowering students to have a choice in the type of education that they obtain creates an education market where competition can thrive. Consequently, this is the same motivation that has spurred the school choice movement in the United States over the past decade.

School choice has in many ways been one of the most controversial issues discussed in the literature when it comes to education reform. Proponents argue that competition among schools is the only mechanism suitable for improving our current education system. Opponents of choice, however, fear that choice programs will drain muchneeded support away from the schools in most need of public funds. With the recent expansion of programs such as charter schools, vouchers, and open enrollment, it is important to analyze the impact that these types of school choice options have on student achievement, which will undoubtedly be important for the future of human capital and economic growth.

Currently, researchers focus on either analyzing the achievement levels of those students who leave the traditional public school system to participate in some school choice program, or on estimating the impacts of competition on those students who stay in the traditional public school system (see Rouse 1998; Holmes, DeSimone, and Rupp 2003; and Hoxby 2004 for a few examples). This strand of literature usually focuses on measuring student outcomes through a production function. Most empirical models measure student output through some form of standardized achievement exam using inputs such as school characteristics, teacher characteristics, neighborhood effects, and peer effects as controls. 
For this analysis, I take a different approach by analyzing the impacts of school choice on economic growth. Just as improving student achievement is an important policy issue when it comes to education reform, so is the economic development of regions. Because school choice gives parents the opportunity to choose where to send their children to school, it would make sense that the more options they have, the more likely they would be to stay in a region, or move to a region where their options are plentiful. This idea can also be attributed to Tiebout (1956), who models the provision of public services by local governments. Tiebout's key insight is that when citizens are faced with an array of communities that offer different types or levels of public goods and services, each citizen will choose the community that best satisfies his or her own particular demands. Individuals effectively reveal their preferences by "voting with their feet." For example, people with high demands for education will concentrate themselves in communities with high levels of educational choice and high taxes, while those with low demands will choose other communities with low levels of educational choice and low taxes. Competition among jurisdictions results in homogeneous communities, with residents who all value public services similarly. In equilibrium, no individual can be made better off by moving and the market is efficient.

In this paper, I use population growth as the determinant of regional economic growth while measuring the impact of school choice on regional development. The results indicate that school choice in the form of charter schools impacts population growth positively, implying that policymakers need to consider educational options for parents as a tool for improving the development of the regional economy.

The paper proceeds as follows. Section 2 defines the three school choice programs used in the analysis. Section 3 identifies the two most common frameworks used for modeling population growth, and Section 4 describes the data used in the study. The empirical model and the results, indicating the impact of school choice on population growth, are presented in Section 5. Finally, Section 6 presents concluding thoughts and policy implications of the analysis.

\section{SCHOOL CHOICE PROGRAMS}

The variables of interest in this analysis are the three most common forms of school choice options in the U.S., charter schools, vouchers, and open enrollment. Charter schools are publicly funded, privately run schools providing a viable alternative for parents and students who are unsatisfied with the traditional public school system. The Center for Education Reform defines charter schools as follows:

Charter schools are independent public schools, designed and operated by educators, parents, community leaders, educational entrepreneurs and others. They are sponsored by designated local or state educational organizations who monitor their quality and integrity, but allow them to operate freed from the traditional bureaucratic and regulatory red tape that hog-ties public schools. Freed from such micromanagement, 
charter schools design and deliver programs tailored to educational excellence and community needs. Because they are schools of choice, they are held to the highest level of accountability - consumer demand.

Since the nation's first charter school legislation was enacted in Minnesota in 1991, 40 states and the District of Columbia have enacted legislation that provides for charter schools. As of January 2005, approximately 3,400 charter schools were in operation, serving almost one million students. ${ }^{1}$

Another common form of school choice is known as the "educational voucher," which allows students to use public money to attend any private or public school of their choosing. ${ }^{2}$ As defined by the Education Commission of the States (ECS), a publicly funded voucher is "a payment made to a parent, or to an institution on the parent's behalf, to be used for a child's education expenses."3 A voucher-like program has existed in Vermont and Maine for over a century, providing students without a school district in their area an opportunity to be educated elsewhere. Vouchers have also been used in Milwaukee, Wisconsin, Cleveland, Ohio, Florida, and most recently in the District of Columbia to help the plight of low-performing schools and to aid low-income families.

Open enrollment is another school choice option for unsatisfied parents and students, allowing students to transfer among public schools within their states. Open enrollment has four forms: intradistrict mandatory, interdistrict mandatory, intradistrict voluntary, and interdistrict voluntary. The intradistrict open enrollment laws allow choice of public schools within district boundaries. The interdistrict open enrollment laws allow choice of public schools across district boundaries. Mandatory open enrollment laws require districts to allow students to transfer, and voluntary open enrollment laws allow districts to choose whether to allow students to transfer to a school of their choice. Currently only the states of Alabama, Maryland, North Carolina, Virginia, and the District of Columbia have no open enrollment laws. ${ }^{4}$

\section{A FRAMEWORK}

Beeson, Dejong, and Troesken (2001) generalize growth models into two classes. The first model, commonly referred to as a neoclassical framework, assumes productivity is exogenous. In the urban and regional growth literature, differences in productivity are

\footnotetext{
${ }^{1}$ Figures come from the Center for Education Reform, www.edreform.com.

${ }^{2}$ Not all schools choose to participate in the voucher program, so a student's options can be limited depending on the particular area.

${ }^{3}$ Although the publicly funded voucher is by far the most widely studied, there are also privately funded vouchers as well. A privately funded voucher is a payment that a private organization makes to a parent or an institution on a parent's behalf, to be used for a child's education expenses. Two of the more notable privately funded efforts are the Children First America (CFA) and the Children's Scholarship Fund (CSF).

${ }^{4}$ Education Commission of the States, 2003.
} 
assumed to come from variations in resource endowments. Regions may differ in their endowments of capital and labor or in their endowments of natural resources such as access to rivers and ports (e.g., Borts 1960). In this type of analysis, a difference in population growth represents adjustment to a steady state. Factor productivity and factor returns will vary across locations due to initial differences in endowments, and the movement of factors to equalize returns will be reflected in a convergence of population levels. Therefore, in this model, all regions will grow at the same rate once population is located optimally and a steady state has been achieved.

The second class of models used to explain growth allows productivity differences to be endogenous. These models are referred to as "cumulative causation models" in the urban and regional literature (e.g., Mydral 1957; Kaldor 1970) and as "endogenous growth models" in the macroeconomic literature, (e.g., Romer 1986; Lucas 1988). In these models, populations are again assumed to concentrate in areas with natural advantages. In contrast to the exogenous growth model, however, cumulative causation models predict that productivity can be amplified over time. An initial concentration of people can create additional advantages that increase the value of the location. Examples include agglomeration economies such as economies of scale in production and consumption, knowledge spillovers, and labor market externalities.

In this paper, I employ a variation of a general cumulative causation model of population growth and complement the current empirical literature in an important way. Although many studies focus on human capital and education as factors contributing to regional economic growth (e.g., Romer 1986; Carlino and Mills 1987; Murphy and Welch 1992), none directly study the impacts of school choice on the growth of regions.

From a theoretical standpoint, public finance models often include school quality as a major determinant of household location choices and, in turn, of neighborhood stratification. As the Tiebout hypothesis predicts, households will choose their residential location based on the mix of taxes and services that most closely resemble their preferences. In analyzing the effects of school choice on regional economic growth, it is important to consider why households would value the ability to select schools for their children. If we assume that parents choose schools based on their productivity, one might expect that school choice would be a factor contributing to location decisions given that choice has been shown to improve school productivity (e.g., Hoxby 2003). In addition, studies have shown that households place a high value on the characteristics of peers and neighbors (e.g., Bayer, Ferreira, and McMillan 2003; Epple and Romano 1998). Using inter-district choice, Urquiola (2005) finds that increased district availability affects students' district and school-level peer groups, thus providing evidence that school choice could play a major role in location decisions and therefore contribute to regional economic growth. 


\section{DATA}

To estimate the impact of school choice on regional economic growth, I use U.S. county-level data on population from the 1990 and 2000 U.S. Census. The data includes 2,962 U.S. counties, excluding all counties in Alaska, Hawaii, and the District of Columbia. $^{5}$ A complete listing of the variables with their descriptive statistics can be found in Table 1. The school choice variables in the regression include charter schools, vouchers, and open enrollment. The charter school and voucher variables are used as dummies and were collected from the National Center for Education Statistics and the Education Commission of the States, respectively. The charter dummy was collected for 1993 because charter school legislation was not passed until 1991 and the first charter schools did not open until 1992. Voucher data was collected only for 1990 because there were no significant changes in the number of voucher programs until after 1995.

\section{TABLE 1}

\section{Descriptive Statistics}

\begin{tabular}{lrrrr}
\hline & & \multicolumn{1}{c}{ Standard } \\
Variable & Mean & Deviation & \multicolumn{1}{c}{ Min } & \multicolumn{1}{c}{ Max } \\
\hline log Population 2000- log Population 1990 & 1.17 & 1.60 & 0.02 & 73.58 \\
Population 1990 & $81,082.04$ & $266,491.17$ & 727.00 & $5,105,067.00$ \\
Charter 93 & 0.19 & 0.39 & 0.00 & 1.00 \\
Voucher 90 & 0.01 & 0.10 & 0.00 & 1.00 \\
Open Enrollment 90 & 0.31 & 0.68 & 0.00 & 3.00 \\
Open Enrollment 93 & 0.40 & 0.71 & 0.00 & 3.00 \\
Percent White & 87.66 & 15.00 & 9.97 & 100.00 \\
Percent Male & 48.97 & 1.53 & 45.03 & 65.89 \\
Median Age & 37.33 & 3.86 & 20.70 & 54.30 \\
Percent with High School Degree & 77.36 & 8.66 & 34.70 & 96.96 \\
Percent with Bachelors Degree & 42.56 & 11.15 & 16.91 & 85.39 \\
Unemployment Rate & 6.58 & 2.92 & 0.18 & 25.49 \\
log Median Income & 24.28 & 6.74 & 9.79 & 62.75 \\
Crime Index & 3.56 & 13.84 & 0.00 & 383.72 \\
Amenity & 0.03 & 2.27 & -6.40 & 11.17 \\
Rural/Urban Code & 5.53 & 2.70 & 0.00 & 9.00 \\
Industry Mix & -0.63 & 1.80 & -25.54 & 23.39 \\
Economic Freedom Index & 6.97 & 0.41 & 5.90 & 7.90 \\
\hline
\end{tabular}

\footnotetext{
5 The independent cities of Virginia were included in the data set by constructing a population weighted average for all of the variables included in the model.
} 
The open enrollment variable was also collected from the Education Commission of the States. The first specification is used as an index taking the value of 0 if the county had no open enrollment at all by 1990, 1 if it had either interdistrict or intradistrict voluntary open enrollment, 2 if it had at least one mandatory open enrollment policy, or 3 if it had both interdistrict and intradistrict mandatory open enrollment policies. The second specification is again used as an index to represent those counties that had adopted open enrollment policies by 1993 or had changed their policy between 1990 and 1993. The demographic and other control variables for this analysis were obtained from the 1990 and 2000 Census, the Federal Bureau of Investigation, the Bureau of Labor and Statistics, the United States Department of Agriculture and the Frasier Institute.

\section{EMPIRICAL MODEL}

The empirical model follows the current literature on determining population growth (see Barro and Sala-i-Martin 1992; Glaeser, Scheinkman, and Shleifer 1995; Beeson, Dejong, and Troesken 2001). Using OLS, I estimate the following,

$$
\begin{aligned}
& \text { Population }_{i x}-\text { Population }_{i y}=\alpha+\beta_{1} \text { Population }_{i y}+\beta_{2} \text { Charter }+\beta_{3} \text { Voucher }+ \\
& \beta_{4} \text { OpenEnrollment90 } \beta_{5} \text { OpenEnrollment93 }+\beta_{6} \text { White }_{i}+\beta_{7} \text { Male }_{i}+\beta_{8} \text { Age }_{i}+ \\
& \beta_{9} \text { HighSchool }_{i}+\beta_{10} \text { Bachelors }_{i}+\beta_{11} \text { Unemployment }_{i}+\beta_{12} \text { MedianIncome }_{i}+ \\
& \beta_{13} \text { Crime }_{i}+\beta_{14} \text { Amenity }_{i}+\beta_{15} \text { RuralUrbanCodei }+\beta_{16} \text { IndustryMixi }+ \\
& \beta_{17} \text { NeighborIndustryMix }_{i}+\beta_{18} \text { EconomicFreedomIndex }_{i}+\varepsilon_{\mathrm{i}}
\end{aligned}
$$

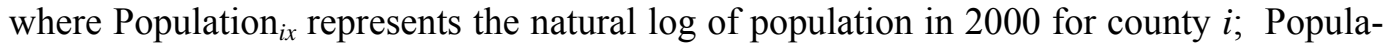
tion $_{i y}$ is the natural $\log$ of population for county $i$ in 1990; Charter is a dummy equal to 1 if a charter school was present in 1993; Voucher is a dummy equal to 1 if a voucher program was present in 1990; OpenEnrollment90 and OpenEnrollment93 represent whether a county had instituted an open enrollment policy by 1990 and 1993, respectively, and of what type; White $_{i}$ is the percent of the population that was white in 1990; $\mathrm{Male}_{i}$ is the percent of the population that was male in 1990; $\mathrm{Age}_{i}$ is the median age of the population in 1990; HighSchool ${ }_{i}$ and Bachelors ${ }_{i}$ are the education controls representing the percent of the population that had at least a high school degree and at least a bachelors degree in 1990, respectively; Unemployment ${ }_{i}$ is the unemployment rate in 1990; MedianIncome ${ }_{i}$ is the natural log of median income for 1990; Crime ${ }_{i}$ is the crime rate per 100,000 inhabitants for the year 2000; Amenity ${ }_{i}$ represents the natural amenities scale, which measures physical characteristics of a county that enhance a location as a

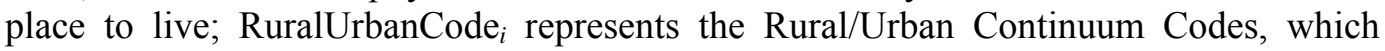
classifies counties by population; IndustryMix ${ }_{i}$ is the industry mix variable calculated from the shift-share model; NeighborIndustryMix ${ }_{i}$ is a weighting matrix that accounts for the effects of employment growth in neighboring counties; EconomicFreedomIndex ${ }_{i}$ is a 
variable accounting for the differences between states on a variety of issues such as taxes, expenditures, and labor market freedom; and $\varepsilon_{\mathrm{i}}$ is the random error term. ${ }^{6}$

The OLS regression results are presented in column 1 of Table 2. The findings for the demographic variables are similar to what is found in other studies. The percent of the population with a bachelors degree, percent male, and percent white are all positive and significant; log of population for 1990, crime, and median age were found to be negative and significant. Amenity and the Rural/Urban Code variables were included to control for specific characteristics of the county. Amenity was found to be positive and significant, as expected. The Rural/Urban Code was found to be negative and significant, indicating that more rural areas will see less population growth. ${ }^{7}$ Industry Mix, which accounts for employment growth, was found to be positive and significant, indicating that counties with a favorable mix of industries will see population growth in those regions. In addition, a weighting matrix was used to account for employment growth in neighboring counties. This variable was found to be negative and significant, indicating that counties with neighbors who have a favorable industry mix will experience a negative impact on population growth. The Economic Freedom Index, which was included to account for tax, expenditure, and labor market differences between states, was found to be positive and significant, indicating that "freer" states see higher rates of population growth. For the school choice variables, charter schools were found to be a positive and significant contributing factor to population growth. Vouchers and open enrollment were found to be insignificant. The insignificant finding may be attributable to the small number of students actually participating in voucher and open enrollment options during this time period.

Although the majority of the coefficient estimates found by using OLS are in line with what is expected, the possibility of spatial dependence in cross-sectional data at the county level calls into question the reliability of this finding. Therefore, in addition to running OLS, a model used to correct for spatial dependence was also applied to Equation (1). Pioneered by Cliff and Ord (1981) and Anselin (1988), models of spatial dependence are used to account for direct influence from spatial neighbors as well as spillover effects between cross-sectional units of observation. When performing OLS in the presence of spatial autocorrelation, coefficient estimates may be biased and inconsistent or inefficient. The model of spatial autocorrelation allows for spatial dependence in

\footnotetext{
${ }^{6}$ The year 2000 was used for crime due to better data availability. This variable was also excluded to check for endogeneity. The exclusion of this variable had no significant impacts on the results reported in column 1 of Table 2. In addition to using a single linear variable to represent the Rural/Urban Continuum Codes, another specification that included a series of eight dummies to represent the codes was analyzed. The results were very similar to those reported in column 1 of Table 2. The 1989 freedom index used in this analysis was taken from the Economic Freedom of North America: 2004 Annual Report.

7 The Rural/Urban Code variable was created using a classification scheme developed by the United States Department of Agriculture. See www.ers.usda.gov/briefing/Rurality/RuralUrbCon/ for a full description of the classification scheme.
} 
TABLE 2

\begin{tabular}{|c|c|c|c|c|}
\hline \multicolumn{5}{|c|}{ Impacts of School Choice on Population Growth } \\
\hline Variable & OLS & SAR & SEM & SAC \\
\hline constant & -0.2934 & $-0.1337^{* * *}$ & -0.0965 & -0.0353 \\
\hline Charter93 & $0.0456^{* * *}$ & $0.0319^{* * *}$ & $0.0445^{* * *}$ & $0.0549^{* * *}$ \\
\hline Voucher90 & -0.0051 & 0.0066 & 0.0238 & 0.0443 \\
\hline Open Enrollment90 & 0.0004 & 0.00085 & -0.0045 & 0.0066 \\
\hline Open Enrollment93 & 0.0089 & 0.0039 & 0.0099 & 0.0178 \\
\hline logpop90 & $-0.0370^{* * *}$ & $-0.0376^{* * *}$ & $-0.0493^{* * *}$ & $-0.0543^{* * *}$ \\
\hline Unemployment Rate & 0.0022 & 0.0023 & $0.0040^{* *}$ & $0.0047^{* *}$ \\
\hline log Median Income & -0.0262 & $-0.0454^{*}$ & $-0.0521^{*}$ & $-0.0596^{*}$ \\
\hline Percent with High School Degree & -0.0011 & -0.0011 & -0.0015 & -0.0018 \\
\hline Percent with Bachelors Degree & $0.0022^{* * *}$ & $0.0027^{* * *}$ & $0.0042^{* * *}$ & $0.0051^{* * *}$ \\
\hline Percent Male & $0.0139^{* * *}$ & $0.0122^{* * *}$ & $0.0115^{* * *}$ & $0.0108^{* * *}$ \\
\hline Percent White & $0.0012^{* * *}$ & $0.0012^{* * *}$ & $0.0016^{* * *}$ & $0.0018^{* * *}$ \\
\hline Crime Index & $-0.0029^{* * *}$ & $-0.0030^{* * *}$ & $-0.0029^{* * *}$ & $-0.0026^{* * *}$ \\
\hline Median Age & $-0.0059^{* * *}$ & $-0.0047^{* * *}$ & $-0.0050^{* * *}$ & $-0.0051^{* * *}$ \\
\hline Amenity & $0.0199^{* * *}$ & $0.0148^{* * *}$ & $0.0210^{* * *}$ & $0.0255^{* * *}$ \\
\hline Rural/Urban Code & $-0.0334^{* * *}$ & $-0.0322^{* * *}$ & $-0.0355^{* * *}$ & $-0.0351^{* * *}$ \\
\hline Industry Mix & $0.0143^{* * *}$ & $0.0140^{* * *}$ & $0.0128^{* * *}$ & $0.0119^{* * *}$ \\
\hline Neighbor Industry Mix & $-0.0095^{* *}$ & $-0.0130^{* * *}$ & $-0.0121^{* *}$ & -0.0091 \\
\hline Economic Freedom Index & $0.0636^{* * *}$ & $0.0486^{* * *}$ & $0.0649^{* * *}$ & $0.0700^{* * *}$ \\
\hline rho & & $0.3000^{* * *}$ & & $-0.3010^{* * *}$ \\
\hline lambda & & & $0.3710^{* * *}$ & $0.5780^{* * *}$ \\
\hline Observations & 2,692 & 2,692 & 2,692 & 2,692 \\
\hline R-squared & 0.1968 & 0.1860 & 0.2640 & 0.3101 \\
\hline
\end{tabular}

the dependent variable, called a spatial lag, or in the error component, termed a spatial error lag. The first-order spatial lag model can be expressed as:

$$
y=\rho W y+X \beta+\varepsilon
$$

where $y$ is the $(N \times 1)$ dependent variable, $\rho$ is a scalar and the spatial autoregressive coefficient, $W$ is a $(N \times N)$ spatial weighting or contiguity matrix, $X$ is a $(N \times K)$ matrix of exogenous variables, and $\varepsilon$ is the $(N \times 1)$ random error term.

I use a first order contiguity weighting matrix to capture the possible effects of spillovers and the direct influence of neighboring schools. Intuitively, it is possible that school choice in one area could affect the laws and regulations in a neighboring region. In addition, one could argue that people may live in one county but send their child to a neighboring county to be educated. Therefore, counties that are close to one another should have weights to account for these possible influences. 
The spatial lag model presented above assumes spatial correlation in the dependent variable only, which may arise because of simultaneous interaction between counties. For example, the contiguity matrix $W$ defined above supposes that school choice options are correlated for counties within close proximity to one another. However, spatial correlation may also occur due to spatial correlation in the error term. Spatially correlated errors may occur due to spatial correlation among the explanatory variables, omitted variables, or spatial correlation in the dependent variable. To model spatial error dependence, I assume a first-order spatial autoregressive structure where the error term is given as:

$$
\varepsilon=\lambda W \varepsilon+v=(I-\lambda W)^{-1} v
$$

where $\varepsilon$ is the $(N \times 1)$ vector of error terms, $v$ is a $(N \times 1)$ component of the error terms made up of IID random variables, $W$ is a $(N \times N)$ spatial weighting or contiguity matrix, and $\lambda$ is a scalar interpreted as the unobserved spatial error correlation coefficient. The error terms are positively correlated if $\lambda>0$, negatively correlated if $\lambda<0$, and not correlated if $\lambda=0$.

The results of both the spatial lag model and the spatial error lag model are reported in columns 2 and 3 in Table 2. When considering these two models, the estimates for both $\rho$ and $\lambda$ are positive and significant at a 1 percent level based on a t-test, revealing positive spatial correlation in the lagged dependent variable and positive spatial correlation in the error terms. The coefficient estimates using MLE in both the spatial lag model and the spatial error lag models were similar to what was found in the OLS regression. The only changes were in the median income variable, which became negative and significant in both specifications, and unemployment, which became positive and significant in the spatial error lag estimation. In both the spatial lag and spatial error lag models, the charter school coefficient estimates were again positive and significant, contributing to an approximate increase in population growth of between 3.2 and 4.5 percent, while vouchers and open enrollment were found to be insignificant.

When examining the log-likelihood ratios from the spatial lag and spatial error lag models, marginal evidence is found in favor of using the spatial error model. However, it is possible that in the spatial error model there is still the potential for some spatial dependence in the dependent variable. To test for this, I conducted an LM test and found the chi-squared value to be large enough to reject the null of no autocorrelation in the dependent variable. This suggests that a general spatial autocorrelation model should be used. The spatial autocorrelation model can be expressed as follows.

$$
y=\rho W y+X \beta+(I-\lambda W)^{-1} v
$$

The results of the general spatial autocorrelation model are presented in column 4 in Table 2. The coefficient estimates for the general spatial autocorrelation are very similar to those found in the spatial lag model. In this specification, charter schools were found to contribute to an approximate 5.5 percent increase in population growth. 


\section{CONCLUSION}

Based on the empirical analysis presented in this paper, there is some evidence that school choice has a positive influence on population growth. When considering the timeframe of this study, many school choice programs were just starting to gain ground in terms of the legislation in various states that permit such school choice options and in the percentage of students participating. Therefore, as we move into the future, it is important for policymakers to consider school choice options as an important component for both education reform and for regional economic development strategies. For example, location decisions of firms are influenced in large part by the provision of public services. The public sector provides services consumed directly by the firm and also provides goods consumed by the area's workforce. Education is a public service of high importance to many families when choosing an area in which to live. According to the results of this paper, families may be more apt to move to a region that provides them with a variety of educational opportunities for their children.

Developing policies that create education options for parents could be one way to attract people to a region. Attracting families to a region can increase the potential for entrepreneurial activity, which was first suggested by Schumpeter (1911) to be a source for economic growth and has also been linked to the success of urban industrial growth (e.g., Chinitz 1962).

Additional benefits of attracting families through educational options can be found in the positive production spillovers that schooling creates. Glaeser, Scheinkman, and Shleifer (1995) find evidence that a connection between growth and initial schooling in urban centers does exist, supporting the view that education through spillovers generates growth. Due to the positive role that education provides in generating growth, school choice increases the likelihood that positive spillovers will be created through integrating competition and parental choice into the education market. Finding a relationship between charter schools and population growth implies that school choice policies are working to attract families to regions with educational options. Continued efforts in the school choice movement should therefore be pursued for the future development of economic regions.

\section{REFERENCES}

Anselin, L., 1988. Spatial Econometrics: Methods and Models. Kluwer Academic Publishers: Dordrecht.

Barro, R.J. and X. Sala-I-Martin, 1992. "Public Finance in Models of Economic Growth," Review of Economic Studies 59, 645-662.

Bayer, P., F. Ferreira, and R. McMillan, 2003. "A Unified Framework for Measuring Preferences for Schools and Neighborhoods," Economic Growth Center, Yale University Working Paper No. 872.

Beeson, P.E., D.N. Dejong, and W. Troesken, 2001. "Population Growth in U.S. Counties, 1840-1990," Regional Science and Urban Economics 31, 669-699. 
Borts, G., 1960. "The Equalization of Returns and Regional Economic Growth," American Economic Review 50(3), 319-347.

Carlino, G.A. and E.S. Mills, 1987. "The Determinants of County Growth," Journal of Regional Science 27(1), 39-54.

Center For Education Reform, 2000. Charter Schools Today: Changing the Face of American Education. Center for Educational Reform: Washington, D.C. Available at: http://edreform.com/charter_schools/today/index.html, July.

Cliff, A. and J. Ord, 1981. Spatial Processes, Models, and Applications. Pion: London.

Chinitz, B., 1962. "Contrasts in Agglomeration: New York and Pittsburgh," American Economic Review Papers and Proceedings 52(2), 279-289.

Education Commission of the States, 2003. "School Choice State Laws: 50-State Profile." Available at: http://mb2.ecs.org/reports/Report.aspx?id=205, July.

Epple, D. and R.E. Romano, 1998. "Competition Between Public and Private Schools, Vouchers, and Peer-Group Effects," American Economic Review 88(1), 33-62.

Glaeser, E.L., J.A. Scheinkman, and A. Shleifer, 1995. "Economic Growth in a CrossSection of Cities," Journal of Monetary Economics 36(1), 117-143.

Holmes, G.M., J. DeSimone, and N.G. Rupp, 2003. "Does School Choice Increase School Quality?" National Bureau of Economic Research Working Paper 9683: Cambridge, MA.

Hoxby, C.M., 2003. "School Choice and School Productivity (Or, Could School Choice be a Rising Tide that Lifts All Boats)," in C. Hoxby (ed.), The Economics of School Choice. The University of Chicago Press, 287-341.

, 2004. "A Straightforward Comparison of Charter Schools and Regular Public Schools in the United States," Harvard University and National Bureau of Economic Research.

Kaldor, N., 1970. "The Case for Regional Policies," Scottish Journal of Political Economy 17(3), 337-347.

Lucas, R., 1988. "On the Mechanics of Economic Development," Journal of Monetary Economics 22(1), 3-42.

Mydral, K.G., 1957. Economic Theory and Underdeveloped Regions. Duckworth Press: London.

Murphy, K. and F. Welch, 1992. "The Structure of Wages," Quarterly Journal of Economics 107(1), 285-326.

Romer, P., 1986. "Increasing Returns and Long-Run Growth," Journal of Political Economy 94(5), 1002-1037.

Rouse C., 1998. "Private School Vouchers and Student Achievement: An Evaluation of the Milwaukee Parental Choice Program," Quarterly Journal of Economics 113(2), 553-602.

Schumpeter, J., 1911 (Reprinted in 1936). Theory of Economics Development. Harvard University Press: Cambridge.

Smith, A., 1776. An Inquiry into the Nature and Causes of the Wealth of Nations. Encyclopedia Britannica, Chicago, c1952.

Tiebout, C., 1956. "A Pure Theory of Local Public Expenditures," Journal of Political Economy 64(4), 416-424. 
Urquiola, M., 2005. "Does School Choice Lead to Sorting? Evidence from Tiebout Variation," American Economic Review 95(4), 1310-1326.

U.S. Bureau of Labor, Bureau of Labor Statistics, 2004. Available at: www.bls.gov/bls/ employment.htm, July.

U.S. Department of Agriculture, Economic Research Service, 2004. Available at: www.ers.usda.gov/briefing/Rurality/RuralUrbCon/, October.

U.S. Department of Commerce, Bureau of the Census, 1990. Census of Population and Housing, Summary Tape File 1. General Printing Office: Washington, D.C.

, 2000. Census of Population and Housing, Summary Tape File 1. General Printing Office: Washington, D.C. , 2000. Census of Population and Housing, Summary Tape File 2. General Printing Office: Washington, D.C.

U.S. Department of Education, Common Core of Data, School Year 1990-91, National Center for Education Statistics: Washington, D.C.

U.S. Department of Justice, Federal Bureau of Investigation, Uniform Crime Reports, 2004. Available at: www.fbi.gov/ucr/ucr.htm, July. 